\title{
Pseudoalteromonas spongiae sp. nov., a novel member of the $\gamma$-Proteobacteria isolated from the sponge Mycale adhaerens in Hong Kong waters
}

Correspondence

Pei-Yuan Qian

boqianpy@ust.hk

\author{
Stanley C. K. Lau, ${ }^{1}$ Mandy M. Y. Tsoi, ${ }^{1}$ Xiancui Li, ${ }^{1}$ Sergey Dobretsov, ${ }^{1}$ \\ Yulia Plakhotnikova, ${ }^{1}$ Po-Keung Wong ${ }^{2}$ and Pei-Yuan Oian ${ }^{1}$ \\ ${ }^{1}$ Coastal Marine Laboratory/Department of Biology, Hong Kong University of Science and \\ Technology, Clear Water Bay, Kowloon, Hong Kong \\ ${ }^{2}$ Department of Biology, Chinese University of Hong Kong, Shatin, N.T., Hong Kong
}

A Gram-negative, non-spore-forming, short rod-shaped bacterium (UST010723-006 ${ }^{\top}$ ) was isolated from the surface of the sponge Mycale adhaerens in Hong Kong waters. Cells of UST010723-006 ${ }^{\top}$ did not have flagella and were non-motile. Colonies were pale orange in colour, 2-4 $\mathrm{mm}$ in diameter, convex with a smooth surface and an entire translucent margin. Gas bubbles were observed in the colonies and also in the agar matrix underneath and adjacent to the colonies. UST010723-006 ${ }^{\top}$ was heterotrophic, strictly aerobic and required $\mathrm{NaCl}$ for growth $(2 \cdot 0-6 \cdot 0 \%)$. It grew at $\mathrm{pH} 5 \cdot 0-10 \cdot 0$ and between 12 and $44^{\circ} \mathrm{C}$. Phylogenetic analysis of the 16S rRNA gene sequence placed UST010723-006 ${ }^{\top}$ within the genus Pseudoalteromonas of the $\gamma$-subclass of the Proteobacteria. The DNA G $+\mathrm{C}$ content is $40.6 \mathrm{~mol} \%$ and the dominant fatty acids were $12: 03-\mathrm{OH}, 14: 0,15: 0$ iso $2-\mathrm{OH}, 16: 0,16: 1 \omega 7,17: 1 \omega 8$ and $18: 1 \omega 7$ (altogether representing $75 \cdot 9 \%$ of the total).These data supported the affiliation of UST010723-006 ${ }^{\top}$ to the genus Pseudoalteromonas. The closest relatives were Pseudoalteromonas luteviolacea, $P$. phenolica, $P$. rubra and $P$. ruthenica with similarity values ranging from $95 \cdot 4$ to $96 \cdot 8 \%$. UST010723-006 ${ }^{\top}$ differed from these closest relatives by $9-19$ traits. Molecular evidence, together with phenotypic characteristics, suggests that UST010723-006 ${ }^{\top}$ constitutes a novel species within the genus Pseudoalteromonas. The name Pseudoalteromonas spongiae sp. nov. is proposed for this bacterium. The type strain is UST010723-006 ${ }^{\top}\left(=\right.$ NRRL B- $41100^{\top}=$ JCM $\left.12884^{\top}\right)$.
The genus Pseudoalteromonas currently comprises 32 described members; many isolated from marine macroorganisms, such as Pseudoalteromonas ruthenica from mussels and scallops (Ivanova et al., 2002a), Pseudoalteromonas maricaloris from sponges (Ivanova et al., 2002b), Pseudoalteromonas tunicata from tunicates (Holmström et al., 1998) and Pseudoalteromonas ulvae from algae (Egan et al., 2001). They are often suggested to have important ecological implications for the survival and fitness of the host organism (Holmström et al., 2002). In this study, we describe a novel member of Pseudoalteromonas isolated from the surface of a sponge in subtropical water.

Published online ahead of print on 4 March 2005 as DOI 10.1099/ ijs.0.63638-0.

The GenBank/EMBL/DDBJ accession number for the $16 \mathrm{~S}$ rRNA gene sequence of strain UST010723-006 ${ }^{\top}$ is AY769918.

Supplementary material available in IJSEM Online comprises a table showing primers used for the construction of $16 \mathrm{~S}$ rRNA gene sequences, TEM and SEM images and a table detailing the carbohydrate metabolism of strain UST010723-006'.
During the characterization of bacteria isolated from the surface of the sponge Mycale adhaerens in Hong Kong waters, the strain UST010723-006 ${ }^{\mathrm{T}}$ was isolated on nutrient agar (Oxoid) supplemented with $0 \cdot 22$ - $\mu \mathrm{m}$-filtered sea water (referred to as marine agar) at $30^{\circ} \mathrm{C}$. Unless otherwise specified, all characteristics described hereafter were based on cultures grown on marine agar for $48 \mathrm{~h}$ at $30^{\circ} \mathrm{C}$. UST010723-006 ${ }^{\mathrm{T}}$ appeared as pale orange, convex colonies with an entire translucent margin and a smooth surface. No diffusible pigment was observed. Gas bubbles were observed in the colonies as well as in the agar matrix underneath and adjacent to the colonies; this property has not been reported for any of the already described members of Pseudoalteromonas.

The nearly complete $16 \mathrm{~S}$ rRNA gene sequence of UST010723-006 ${ }^{\mathrm{T}}$ (1425 bp) was resolved on a MegaBACE capillary genetic analyser using a dye terminator method according to the manufacturer's protocol. Primers used in the sequencing reactions are detailed in Supplementary Table S1 available in IJSEM Online. Fragments of DNA 


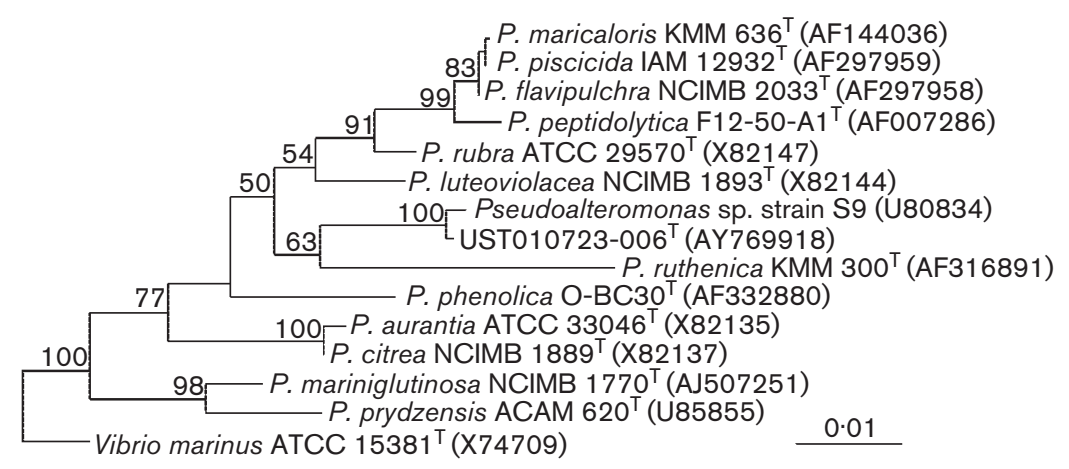

Fig. 1. Neighbour-joining dendrogram showing the estimated phylogenetic relationships among UST010723-006 ${ }^{\top}$ and related Pseudoalteromonas species on the basis of 16S rRNA gene sequences. Vibrio marinus ATCC $15381^{\top}$ was chosen as the outgroup. Scale bar represents 1 nucleotide substitution per 100 nucleotides. Bootstrap values of $>50 \%$ (500 replicates) are indicated at nodes. The GenBank accession number for each reference strain is shown in parentheses. sequence obtained from individual primers with at least six replicates were assembled using the Sequencher software package (Gene Codes). Comparison of the $16 \mathrm{~S}$ rRNA gene sequence of UST010723-006 ${ }^{\mathrm{T}}$ with those available from GenBank revealed that UST010723-006 ${ }^{\mathrm{T}}$ was a member of the $\gamma$-subclass of the Proteobacteria and shared 99.2\% sequence similarity with Pseudoalteromonas sp. S9 (Techkarnjanaruk et al., 1997). A neighbour-joining phylogenetic tree (Fig. 1) constructed using the ARB software package (Ludwig et al., 2004) showed that UST010723$006^{\mathrm{T}}$ and Pseudoalteromonas sp. S9 belonged to a clade (100\% bootstrap value, 500 replications), that did not cluster robustly with any recognized species of Pseudoalteromonas ( $63 \%$ bootstrap value, 500 replications). Trees based on maximum-parsimony and maximum-likelihood methods showed essentially the same topology (data not shown). The results of phylogenetic analysis suggest that UST010723-006 ${ }^{\mathrm{T}}$ represents a novel species within the genus Pseudoalteromonas. The closest relatives of UST010723-006 ${ }^{\mathrm{T}}$ were Pseudoalteromonas luteviolacea (Gauthier, 1982), P. ruthenica (Ivanova et al., 2002a), P. rubra (Gauthier, 1976) and $P$. phenolica (Isnansetyo \& Kamei, 2003) with 96・8, 96•6, 96.5 and $95.4 \%$ sequence identity, respectively.

The dominant cellular fatty acids of UST010723-006 ${ }^{\mathrm{T}}$ are $12: 03-\mathrm{OH}, 14: 0,15: 0$ iso $2-\mathrm{OH}, 16: 0,16: 1 \omega 7,17: 1 \omega 8$ and $18: 1 \omega 7$ (altogether representing $75.9 \%$ of the total; three replications) as determined using the Sherlock Microbial Identification System. This fatty acid profile is similar to that of $P$. ruthenica (Table 1). No fatty acid profiles have been reported for $P$. phenolica, $P$. luteviolacea or $P$. rubra. The DNA G $+C$ content of the strains UST010723-006 ${ }^{\mathrm{T}}$ as determined by the HPLC method of Mesbah et al. (1989) was $40 \cdot 6 \pm 0 \cdot 2 \mathrm{~mol} \%$. This value was similar to those described for P. luteoviolacea and P. phenolica (Table 2).

The phenotypic characteristics of UST010723-006 ${ }^{\mathrm{T}}$ are given in the species description. Anaerobic growth was examined in the Oxoid Anaerobic System. The requirement for $\mathrm{NaCl}$ was tested in a medium containing (per litre) $5 \mathrm{~g}$ $\mathrm{MgCl}_{2}, 2 \mathrm{~g} \mathrm{MgSO}_{4}, 0.5 \mathrm{~g} \mathrm{CaCl}_{2}, 1 \mathrm{~g} \mathrm{KCl}, 5 \mathrm{~g}$ peptone and various amounts of $\mathrm{NaCl}$ adjusted to $\mathrm{pH} 7 \cdot 5$ using $\mathrm{KOH}$ (Isnansetyo \& Kamei, 2003). Cell morphology was examined using scanning electron microscopy (JEOL 7600F) according to Neu et al. (2001). The presence of flagella was examined using light microscopy after Leifson staining according to Smibert \& Krieg (1994) and using transmission electron microscopy (TEM) (JEOL 100 CX) (Grossart et al., 2000) (scanning electron microscopy and TEM pictures are available as Supplementary Fig. S1 in IJSEM Online). Reaction to Gram-stain was determined using light microscopy according to Smibert \& Krieg (1994). Cell motility was determined using both light microscopy and observation of growth in motility medium (Smibert \& Krieg, 1994). Susceptibility to antibiotics was tested according to Acar (1980). Agarase, amylase, catalase, DNase and oxidase activities were tested using the method of Smibert \& Krieg (1994). Substrate utilization patterns and other enzyme activities were tested with the commercial systems API 20E, API 20NE, API 50CH and API ZYM (bioMérieux). Cells for inoculation to the API systems were suspended in sterile solution of sea water mixture at $22 \%$ salinity (MacDonell et al., 1982).

UST010723-006 ${ }^{\mathrm{T}}$ differs from all previously described members of Pseudoalteromonas by testing negative for lipase activity and by the formation of gas bubbles in the

Table 1. Dominant cellular fatty acids of UST010723-006 ${ }^{\top}$ and Pseudoalteromonas ruthenica

Numbers given are the mean percentages $( \pm S D)$ of total fatty acids. Data for Pseudoalteromonas ruthenica are from Ivanova et al. (2002a). NR, not reported by Ivanova et al. (2002a).

\begin{tabular}{|lcc|}
\hline \multirow{2}{*}{$\begin{array}{l}\text { Dominant } \\
\text { fatty acid }\end{array}$} & \multicolumn{2}{c|}{ Content (\%) } \\
\cline { 2 - 3 } & UST010723-006 & P. ruthenica \\
\hline $12: 03-\mathrm{OH}$ & $6 \cdot 9 \pm 1 \cdot 2$ & $\mathrm{NR}$ \\
$14: 0$ & $5 \cdot 3 \pm 1 \cdot 8$ & $2 \cdot 0-11 \cdot 0$ \\
15 iso 2-OH & $29 \cdot 1 \pm 5 \cdot 9^{*}$ & $\mathrm{NR}$ \\
$16: 1 \omega 7$ & $29 \cdot 1 \pm 5 \cdot 9^{*}$ & $31 \cdot 0-42 \cdot 0$ \\
$16: 0$ & $18 \cdot 4 \pm 2 \cdot 9$ & $13 \cdot 8-18 \cdot 7$ \\
$17: 1 \omega 8$ & $9 \cdot 8 \pm 5 \cdot 3$ & $4 \cdot 0-8 \cdot 0$ \\
$18: 1 \omega 7$ & $6 \cdot 4 \pm 1 \cdot 2$ & $4 \cdot 0-16 \cdot 0$ \\
\hline
\end{tabular}

${ }^{\star}$ Appeared as a summed feature comprised of 15 iso $2-\mathrm{OH}$ and $16: 1 \omega 7$. 
colonies (Table 1) (Gauthier et al., 1995). UST010723-006 ${ }^{\mathrm{T}}$ can be distinguished from the four closest relatives $(P$. luteviolacea, P. ruthenica, $P$. rubra and P. phenolica) by 9-19 traits, particularly the lack of amylase activity, flagella and cellular motility (Table 2). Molecular evidence, together with phenotypic characteristics, suggests that UST010723$006^{\mathrm{T}}$ constitutes a novel species within the genus Pseudoalteromonas.

\section{Description of Pseudoalteromonas spongiae sp. nov.}

Pseudoalteromonas spongiae (spon'gi.ae. L. gen. n. spongiae of a sponge).

Cells are Gram-negative, short rods $(1 \cdot 2-1 \cdot 5 \mu \mathrm{m}$ in length and $0.5 \mu \mathrm{m}$ in width) and do not form spores. Cells do not have flagella and are non-motile. Upon cultivation on

Table 2. Differentiation of UST010723-006 ${ }^{\top}$ from other recognized members of Pseudoalteromonas

Data for P. ruthenica, P. luteoviolacea, P. rubra and P. phenolica are from Ivanova et al. (2002a), Gauthier (1982), Gauthier (1976) and Isnansetyo \& Kamei (2003), respectively. +, Positive; (+), weakly positive; -, negative; V, variable; ND, not described. All are oxidase-, DNase- and gelatinase-positive, but are arginine dihydrolase-negative; all utilize glucose, but not D-adonitol, D-arabinose, erythritol, Dgalactose, glycerol, D-lactose, D-mannitol, L-rhamnose or D-sorbitol.

\begin{tabular}{|c|c|c|c|c|c|}
\hline Characteristic & UST010723-006 $^{\mathrm{T}}$ & P. ruthenica & P. luteoviolacea & P. rubra & P. phenolica \\
\hline \multicolumn{6}{|l|}{ Colony } \\
\hline Colour & Pale orange & Pale orange & Purple/yellow & Red & Brown \\
\hline Diffusible pigment & - & - & - & Orange-brown & $\mathrm{ND}$ \\
\hline Gas bubble formation & + & ND & ND & ND & ND \\
\hline \multicolumn{6}{|l|}{ Cell } \\
\hline Flagella & - & + & + & + & + \\
\hline Motility & - & + & + & + & + \\
\hline \multicolumn{6}{|l|}{ Growth: } \\
\hline $\mathrm{NaCl}(\%)$ & $2 \cdot 0-6 \cdot 0$ & $1 \cdot 0-9 \cdot 0$ & $3 \cdot 0-6 \cdot 0$ & $2 \cdot 0-6 \cdot 0$ & $1 \cdot 0-5 \cdot 0$ \\
\hline Temperature $\left({ }^{\circ} \mathrm{C}\right)$ & $8 \cdot 0-44 \cdot 0$ & $10 \cdot 0-35 \cdot 0$ & $10 \cdot 0-30 \cdot 0$ & $10 \cdot 0-37 \cdot 0$ & $18 \cdot 0-37 \cdot 0$ \\
\hline $\mathrm{pH}$ & $5 \cdot 0-10 \cdot 0$ & $6 \cdot 0-10 \cdot 0$ & $>6 \cdot 0$ & $6 \cdot 0-10 \cdot 0$ & $6 \cdot 5-9 \cdot 5$ \\
\hline $\mathrm{G}+\mathrm{C}$ content $(\mathrm{mol} \%)$ & $40 \cdot 6$ & $48 \cdot 4-48 \cdot 9$ & $40 \cdot 9-42 \cdot 2$ & $46 \cdot 7-47 \cdot 3$ & $39 \cdot 9-40 \cdot 6$ \\
\hline \multicolumn{6}{|l|}{ Production of: } \\
\hline Amylase & - & + & + & + & + \\
\hline Catalase & + & + & - & $(+)$ & - \\
\hline Esterase & $+{ }^{a_{\star}}$ & $\mathrm{ND}$ & $\mathrm{ND}$ & - & ND \\
\hline Lipase & $-{ }^{a}$ & + & ND & + & + \\
\hline Lysine decarboxylase & $-{ }^{b}$ & ND & ND & $\mathrm{V}$ & ND \\
\hline Tryptophan deaminase & $-{ }^{b}$ & ND & ND & + & ND \\
\hline \multicolumn{6}{|l|}{ Utilization of: } \\
\hline$N$-Acetylglucosamine & $+{ }^{c}$ & - & ND & ND & + \\
\hline D-Cellobiose & $-{ }^{c}$ & + & - & - & ND \\
\hline D-Fructose & $+{ }^{c}$ & - & - & - & ND \\
\hline Inositol & $+{ }^{c}$ & - & - & - & - \\
\hline Inulin & $+{ }^{c}$ & - & - & - & ND \\
\hline Maltose & $+{ }^{c}$ & - & + & - & + \\
\hline Mannose & $+{ }^{c}$ & - & - & + & + \\
\hline Sucrose & $-{ }^{c}$ & + & - & - & + \\
\hline D-Trehalose & $-{ }^{c}$ & - & + & + & + \\
\hline \multicolumn{6}{|l|}{ Susceptible to: } \\
\hline Kanamycin $(30 \mu \mathrm{g})$ & $-(100 \cdot 0 \mu \mathrm{g})$ & $\mathrm{V}$ & - & $(+)$ & ND \\
\hline Streptomycin $(10 \mu \mathrm{g})$ & $-(100 \cdot 0 \mu \mathrm{g})$ & - & - & $(+)$ & ND \\
\hline Benzylpenicillin $\dagger$ & $+(0 \cdot 1 \mu \mathrm{g})$ & - & - & - & ND \\
\hline Tetracycline $\dagger$ & $+(1.0 \mu \mathrm{g})$ & ND & - & $(+)$ & ND \\
\hline Ampicillin $\dagger$ & $+(0 \cdot 1 \mu \mathrm{g})$ & - & ND & ND & ND \\
\hline
\end{tabular}

${ }^{*}$ Result based on: $a$, API ZYM; $b$, API 20E; $c$, API $50 \mathrm{CH}$.

$\dagger$ Concentration not reported unless specified. 
marine agar, colonies are pale orange in colour, $2-4 \mathrm{~mm}$ in diameter, convex with a smooth surface and an entire translucent margin. Gas bubbles are observed in the colonies and also in the agar matrix underneath and adjacent to the colonies. Growth of UST010723-006 ${ }^{\mathrm{T}}$ is strictly aerobic and occurs between 12 and $44^{\circ} \mathrm{C}$ (but not at 4 or $52^{\circ} \mathrm{C}$ ) and between pH $5 \cdot 0$ and $10 \cdot 0$. UST010723-006 ${ }^{\mathrm{T}}$ requires $\mathrm{NaCl}$ $(2 \cdot 0-6 \cdot 0 \%)$ for growth. The DNA $\mathrm{G}+\mathrm{C}$ content is $40.6 \mathrm{~mol} \%$ and the dominant fatty acids are $12: 03-\mathrm{OH}$, $14: 0,15: 0$ iso $2-\mathrm{OH}, 16: 0,16: 1 \omega 7,17: 1 \omega 8$ and $18: 1 \omega 7$ (altogether representing $75.9 \%$ of the total). Susceptible to benzylpenicillin $(0 \cdot 1 \mu \mathrm{g})$, chloramphenicol $(0 \cdot 1 \mu \mathrm{g})$, ampicillin $(0 \cdot 1 \mu \mathrm{g})$ and tetracycline $(1 \mu \mathrm{g})$. Resistant to streptomycin and kanamycin (tested up to $100 \mu \mathrm{g}$ ). Acetoin, indole and $\mathrm{H}_{2} \mathrm{~S}$ are not produced. Citrate is not utilized. Nitrate is not reduced. $\alpha$-Chymotrypsin, acid phosphatase, alkaline phosphatase, catalase, DNase, esterase (C4), esterase lipase (C8), gelatinase, leucine arylamidase, oxidase, protease and trypsin activities are positive. $N$-Acetyl- $\beta$-glucosaminidase, naphthol-AS-BI-phosphohydrolase and valine arylamidase activities are weakly positive. $\alpha$-Fucosidase, $\alpha$-galactosidase, $\beta$-galactosidase, $\alpha$-glucosidase, $\beta$-glucosidase, $\alpha$-mannosidase, $\beta$-glucuronidase, agarase, amylase, arginine dihydrolase, cystine arylamidase, lipase (C14), lysine decarboxylase, ornithine decarboxylase, tryptophan deaminase and urease activities are negative. Grows on D-glucose, D-fructose, inositol, D-mannose, D-maltose, inulin, $\mathrm{N}$-acetylglucosamine and starch as sole carbon source. Acid is produced from D-maltose and $\mathrm{N}$-acetylglucosamine. Carbohydrates not utilized by UST010723-006 ${ }^{\mathrm{T}}$ are listed in Supplementary Table S2 available in IJSEM Online.

The type strain, UST010723-006 ${ }^{\mathrm{T}}\left(=\mathrm{NRRL} \mathrm{B}-41100^{\mathrm{T}}=\right.$ JCM $12884^{\mathrm{T}}$ ), was isolated from the surface of the sponge Mycale adhaerens in Hong Kong waters.

\section{Acknowledgements}

This work was supported by a Central Allocation Grant of Hong Kong Research Grant Council (CA04/05. Sc01) to P.-Y.Q.

\section{References}

Acar, J. F. (1980). The disc susceptibility test. In Antibiotics in Laboratory and Medicine, pp. 24-54. Edited by V. Lorian. Baltimore: Williams \& Wilkins.

Egan, S., Holmström, C. \& Kjelleberg, S. (2001). Pseudoalteromonas ulvae sp. nov., a bacterium with antifouling activities isolated from surface of a marine alga. Int J Syst Evol Microbiol 51, 1499-1504.
Gauthier, M. J. (1976). Alteromonas rubra sp. nov., a new marine antibiotic-producing bacterium. Int J Syst Bacteriol 26, 459-466.

Gauthier, M. J. (1982). Validation of the name Alteromonas luteoviolacea. Int J Syst Bacteriol 32, 82-86.

Gauthier, G., Gauthier, M. \& Christen, R. (1995). Phylogenetic analysis of the genera Alteromonas, Shewanella, and Moritella using genes for small-subunit rRNA sequences and division of the genus Alteromonas into two genera, Alteromonas (emended) and Pseudoalteromonas gen. nov., and proposal of twelve new species combinations. Int J Syst Bacteriol 45, 755-761.

Grossart, H. P., Steward, G. F., Martinez, J. \& Azam, F. (2000). A simple, rapid method for demonstrating bacterial flagella. Appl Environ Microbiol 66, 3632-3636.

Holmström, C., James, S., Neilan, B. A., White, D. C. \& Kjelleberg, S. (1998). Pseudoalteromonas tunicata sp. nov., a bacterium that produces antifouling agents. Int J Syst Bacteriol 48, 1205-1212.

Holmström, C., Egan, S., Franks, S., McCloy, S. \& Kjelleberg, S. (2002). Antifouling activities expressed by marine surface associates Pseudoalteromonas species. FEMS Microbiol Ecol 41, 47-58.

Isnansetyo, A. \& Kamei, Y. (2003). Pseudoalteromonas phenolica sp. nov., a novel marine bacterium that produces phenolic antimethicillin-resistant Staphylococcus aureus substances. Int J Syst Evol Microbiol 53, 583-588.

Ivanova, E. P., Sawabe, T., Lysenko, A. M. \& 8 other authors (2002a). Pseudoalteromonas ruthenica sp. nov., isolated from marine invertebrates. Int J Syst Evol Microbiol 52, 235-240.

Ivanova, E. P., Shevchenko, L. S., Sawabe, T., Lysenko, A. M., Svetashev, V. I., Gorshkova, N. M., Satomi, M., Christen, R. \& Mikhailov, V. V. (2002b). Pseudoalteromonas maricaloris sp. nov., isolated from an Australian sponge, and reclassification of [Pseudoalteromonas aurantia] NCIMB 2033 as Pseudoalteromonas flavipulchra sp. nov. Int J Syst Evol Microbiol 52, 263-271.

Ludwig, W., Strunk, O., Westram, R. \& 29 other authors (2004). ARB: a software environment for sequence data. Nucleic Acids Res 32, 1363-1371.

MacDonell, M. T., Singleton, F. L. \& Hood, M. A. (1982). Diluent composition for use of API $20 \mathrm{E}$ in characterizing marine and estuarine bacteria. Appl Environ Microbiol 44, 423-427.

Mesbah, M., Premachandran, U. \& Whitman, W. (1989). Precise measurement of the $\mathrm{G}+\mathrm{C}$ content of deoxyribonucleic acid by high-performance liquid chromatography. Int J Syst Bacteriol 39, 159-167.

Neu, B., Voigt, A., Mitlohner, R. \& 7 other authors (2001). Biological cells as templates for hollow microcapsules. J Microencapsul 18, 385-395.

Smibert, R. M. \& Krieg, N. R. (1994). Phenotypic characteristics. In Methods for General and Molecular Biology, pp. 607-654. Edited by P. Gerhardt, R. G. E. Murray, W. A. Wood \& N. R. Krieg. Washington, DC: American Society for Microbiology.

Techkarnjanaruk, S., Pongpattanakitshote, S. \& Goodman, A. E. (1997). Use of a promoterless lacZ gene insertion to investigate chitinase gene expression in the marine bacterium Pseudoalteromonas sp. strain S9. Appl Environ Microbiol 63, 2989-2996. 